\title{
COUMARINS IN ORCHIDACEAE: A REVIEW CONNECTING ETHNOMEDICINE AND THERAPEUTIC EXPECTATIONS
}

\author{
S. Sakthi Priyadarsini and P.R. Kumar ${ }^{凶}$ \\ Department of Pharmacognosy, SRM College of Pharmacy, Faculty of Medicine and Health \\ Sciences, SRM Institute of Science \& Technology, SRM Nagar, Kattankulathur-603203, \\ Kanchipuram, (TamilNadu) India \\ ${ }^{\circledR}$ Corresponding Author: pathangikumar70@gmail.com
}

\begin{abstract}
Orchids hold a strong ethnomedicinal background with varied bioactive compounds including coumarins. The current review explores the coumarin compounds reported in the family of Orchidaceae to achieve better therapeutic expectations. This review was conducted from November 2019 to April 2021 by applying the mixed-method review approach. Ayapin, Coumarin, dihydroayapin, denthyrsin, 3,4-dihydrocoumarin, dendrocoumarin, esculetin, scoparone, scopoletin, scopolin, sinensin A and sinensin B were found to have been reported in orchids. Even though preliminary phytochemical screening of several orchids revealed the presence of coumarins, only a few of them were further investigated for their isolation, identification and pharmacological activity. This lacuna on the role of coumarins in Orchidaceae demanded a further investigation on their ethnomedicinal background. Ethnobotanical surveys conducted by various researchers have substantiated the use of orchids in a varied range of illnesses. Interestingly, the documented folklore claims correlate with the unique anti-inflammatory and anti-edema potential of the coumarin entity. Thus the review highlight the coumarin compounds reported in orchids that could provide better insight for further investigation of this secondary metabolite in the family of Orchidaceae owing to its therapeutic excellence.
\end{abstract}

Keywords: Ayapin, Dendrobium, Denthyrsin, Esculetin, Scoparone, Scopoletin.

RASĀYAN J. Chem., Vol. 14, No.4, 2021

\section{INTRODUCTION}

Orchidaceae, an enriched family among angiosperms, is well known for their distinguished floral diversity with medicinal and commercial importance. ${ }^{1}$ Orchidaceae constitutes over 880 genera and approximately 28000 species. ${ }^{2}$ In spite of its ornamental and economic significance, orchids hold strong and promising folklore claims in treating various diseases and ailments. ${ }^{3-6}$ Coumarins are chemically 5,6benzo-2-pyrone ( $\alpha$-chromone) derivatives with hydroxy, methoxy, or methyl substituents in benzene. ${ }^{7}$ Coumarins were found to be biogenetically derived from phenylpropanoid pathway with cis-cinnamic acid as a key intermediate. ${ }^{8}$

Literature highlights anti-inflammatory, antimicrobial, antioxidant, anticancer, cardiovascular, antithrombotic, anti-tubercular and neuroprotective potential exhibited by natural as well as synthetic coumarins justifying its versatile skeleton. ${ }^{9-15}$ Moreover, the aminocoumarin antibiotics namely, novobiocin, clorobiocin and coumermycin $\mathrm{A}_{1}$ obtained from various strains of Streptomyces act as potent bacterial DNA gyrase inhibitors. ${ }^{16,17}$ The anticoagulants including warfarin, acenocoumarol, phenprocoumon are scientifically proven therapeutically active coumarins. ${ }^{15}$ Also, these oxygenated heterocyclic compounds are reported as potent inhibitors of lipoxygenase (LOX) and cyclooxygenase (COX) pathways in arachidonic acid metabolism. ${ }^{18-20}$ Several scientific reports reveal the presence of coumarins as a key constituent in the phytochemical profile of orchids. However, there remains a lacuna in the documentation of this secondary metabolite in the family of Orchidaceae. A literature search was carried out from November 2019 to April 2021 by applying the mixed-method review approach. Studies on coumarin compounds from several orchid plant extracts with a comprehensive literature review were conducted through electronic databases such as Science Direct, Scopus, Pubmed, Proquest, Google Scholar, Research Gate, etc. 
RASĀYAN $J$. Chem.

Vol. 14 | No. 4 |2591-2597| October- December | 2021

\section{Coumarins in Orchidaceae}

The review determined coumarins including ayapin, coumarin, dihydroayapin, denthyrsin, 3,4dihydrocoumarin, dendrocoumarin, esculetin, scoparone, scopoletin, scopolin, sinensin A and sinensin B in Orchidaceae and was displayed in Table-1. Figure-1 represents the chemical structure of isolated coumarins from different plant parts of Orchidaceae.

Table-1: Coumarins isolated from Various Parts of Orchidaceae

\begin{tabular}{|c|c|c|c|}
\hline Nature of the Coumarin & $\begin{array}{c}\text { Name of the } \\
\text { Coumarin }\end{array}$ & Orchid Source & Part \\
\hline \multirow[t]{14}{*}{ Simple coumarins } & \multirow[t]{2}{*}{ Ayapin } & Dendrobium thyrsiflorum & Leaves $^{23}$, whole plant ${ }^{29}$ \\
\hline & & Dendrobium densiflorum & Stem $^{33,34}$ \\
\hline & \multirow[t]{2}{*}{ Coumarin } & Dendrobium moschatum & Inflorescence, leaves ${ }^{37}$ \\
\hline & & Dendrobium denneanum & Stem $^{38}$ \\
\hline & Denthyrsin & Dendrobium thyrsiflorum & Stem $^{24}$ \\
\hline & Dihydroayapin & Dendrobium densiflorum & Stem $^{33}$ \\
\hline & $\begin{array}{l}3,4 \\
\text { Dihydrocoumarin }\end{array}$ & Dendrobium moschatum & Inflorescence $^{37}$ \\
\hline & Esculetin & Nervilia fordii & Whole plant ${ }^{42}$ \\
\hline & \multirow[t]{2}{*}{ Scoparone } & Dendrobium densiflorum & Stem $^{33,34}$ \\
\hline & & Dendrobium thyrsiflorum & $\begin{array}{l}\text { Leaves, stem, whole } \\
\text { plant }^{23,24,29}\end{array}$ \\
\hline & \multirow[t]{3}{*}{ Scopoletin } & Dendrobium thyrsiflorum & Leaves $^{23}$ \\
\hline & & Dendrobium densiflorum & Stem $^{34}$ \\
\hline & & Habenaria intermedia & Tuber $^{41}$ \\
\hline & Scopolin & Dendrobium densiflorum & Stem $^{33}$ \\
\hline Benzocoumarin & Dendrocoumarin & Dendrobium nobile & Stem $^{39}$ \\
\hline \multirow[t]{2}{*}{ Prenylated comarins } & Sinensin A & Spiranthes sinensis & Root $^{43}$ \\
\hline & Sinensin B & Spiranthes sinensis & Root $^{43}$ \\
\hline
\end{tabular}<smiles>O=c1ccc2cc3c(cc2o1)OCO3</smiles>

Ayapin<smiles>O=C1Cc2c(O)cccc2-c2c1ccc(O)c2Cl</smiles>

Dendrocoumarin<smiles>O=C1CCc2cc3c(cc2O1)OCO3</smiles>

Dihydroayapin<smiles>COc1cc2ccc(=O)oc2cc1OC</smiles>

Scoparone<smiles>O=C1CCc2ccccc2O1</smiles>

3,4 dihydrocoumarin<smiles>COc1cc2ccc(=O)oc2cc1OC1CC(CO)C(O)C(O)C1O</smiles>

Scopoletin<smiles>O=c1ccc2ccccc2o1</smiles>

Coumarin<smiles>COc1cc2cc(-c3cc4cc(OC)c(OC)cc4oc3=O)oc2cc1OC</smiles>

Denthyrsin<smiles>O=c1ccc2cc(O)c(O)cc2o1</smiles>

Esculetin<smiles>COc1cc2ccc(=O)oc2cc1O</smiles>

Scopolin 
RASĀYAN J. Chem.

Vol. 14 | No. 4 |2591-2597| October- December | 2021

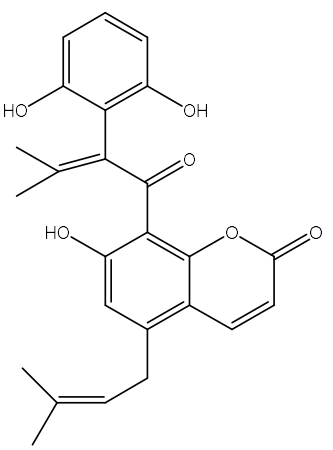

Sinensin A

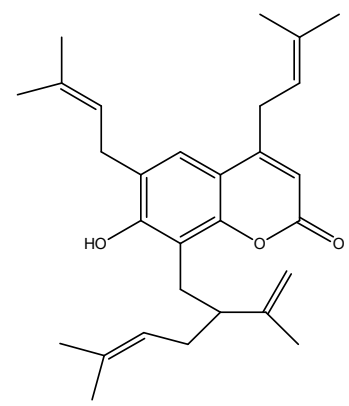

Sinensin B

Fig.-1: Chemical Structure of Coumarins reported in Orchidaceae

\section{Coumarins in Dendrobium thyrsiflorum}

D. thyrsiflorum is characterized by a long cluster of yellow flowers with dark orange lip. ${ }^{21,22}$ The investigation of coumarins was initiated by the study of Wrigley, when the researcher detected ayapin, scopoletin and scoparone (6,7-dimethoxy coumarin) from the leaf hydrolysate of $D$. thyrsiflorum. ${ }^{23} \mathrm{~A}$ study by Zhang et al. has detected scoparone and denthyrsin in the stems of D. thyrsiflorum. Further, the study investigated the cytotoxic potential of these isolated compounds on MCF-7, HeLa and K-562 cancer cells by in-vitro MTT assay. Erianin was used as the positive control for the study. The results of the research revealed that denthyrsin exhibited more cytotoxic activity $\left(\mathrm{IC}_{50}\right.$ between $\left.0.45-18.1 \mu \mathrm{M}\right)$ than scoparone $\left(\mathrm{IC}_{50}>100 \mu \mathrm{M}\right)$ and this was attributed to the coumarins turning more active after coupling with benzofuran. ${ }^{24}$ Also, a qualitative and quantitative analysis of ayapin and scoparone in D.thyrsiflorum was validated using HPLC-DAD-ESI-MS method. ${ }^{25}$

A study by Zheng et al. on the localization and relative quantity of coumarins in the top, middle and basal parts of stem of $D$. thyrsiflorum using laser scanning confocal microscopy (LSCM) suggested the collection of the two-year-old stem during February would be favorable for high yield of coumarins. ${ }^{26}$ Furthermore, the coumarin content and its distribution in the leaf and root of $D$. thyrsiflorum at different developmental stages were studied using LSCM. The study reported coumarins at their highest level during the flowering stage than the fruiting or vegetative period. ${ }^{27}$

Another similar study was carried out by Zheng et al. in the top, middle and basal parts of D. thyrsiflorum stems at the flowering and initial fruiting stages of 1,2 and 3-year-old plants. Coumarins reached their maximum content during the flowering stage, suggesting that harvesting could be carried out when the plants enter the flowering period to achieve the maximum yield of coumarins. The study further reported the distribution of coumarins in vascular bundles and the cell wall of the stems of D. thyrsiflorum. ${ }^{28}$ Additionally, scoparone and ayapin were isolated and characterized from the ethanol extract of $D$. thyrsiflorum. ${ }^{29}$

\section{Coumarins in Dendrobium densiflorum}

D. densiflorum, also known as D. clavatum is characterized by cream to butter yellow-colored flowers. ${ }^{21}$ The leaves were used to set fractures while the pseudobulbs were applied on pimples and boils. ${ }^{30-32}$ According to the study by Zheng et al., the ethanol extract obtained from the fresh stems of $D$. densiflorum was subjected to successive soxhlet extraction for 4 hours with petroleum ether $\left(60-90^{\circ} \mathrm{C}\right)$ followed by chloroform and ethylacetate. Chromatography of the ethylacetate extract over silica gel column using ethyl acetate/petroleum ether (3:7) yielded dihydroayapin. Moreover, scopolin from the petroleum ether extract and ayapin from the chloroform extract was also reported in the study. ${ }^{33}$ Fan et al. reported ayapin, scoparone and scopoletin in the stems of $D$. densiflorum. Further, among the isolated compounds, scopoletin and scoparone were found to possess potent anti-platelet aggregation activity on Sprague-Dawley rats. ${ }^{34}$

\section{Coumarins in Dendrobium moschatum}

The leaves of D. moschatum are used to relieve earaches and the pseudobulbs in treating fractures. ${ }^{35,36}$ Robustelli et al. detected coumarins as the most abundant constituent in the fresh inflorescence and leaves of D. moschatum. When subjected to Gas Chromatography/Flame-Ionization Detection (GC/FID) and 
Gas Chromatography/Mass Spectroscopy (GC/MS) analyses, the coumarins accounted for $2157.1 \mu \mathrm{g} / \mathrm{g}$ $(48.8 \%)$ and $180.1 \mu \mathrm{g} / \mathrm{g}(47.8 \%)$ of the total volatiles from the inflorescence and leaves of $D$. moschatum respectively. Interestingly, 3, 4-dihydrocoumarin was reported in the inflorescence of $D$. moschatum, but the same was found absent in leaves. ${ }^{37}$

\section{Coumarins in Dendrobium denneanum}

A systematic phytochemical study carried out by Pan et al. reported coumarin in the stems of $D$. denneanum. According to the study, the ethanol extract of stems of D. denneanum was further partitioned with n-butanol and chloroform, and the respective fractions were subjected to column chromatography and preparative HPLC. ${ }^{38}$

\section{Coumarins in Dendrobium nobile}

A study by Zhou et al. has reported dendrocoumarin, a benzocoumarin derivative from the stems of $D$. nobile. The study revealed the potent antibacterial effect of dendrocoumarin against Escherichia coli showing a minimum inhibitory concentration (MIC) of $0.6 \mu \mathrm{g} / \mathrm{ml}$ compared to the standard $(0.3 \mu \mathrm{g} / \mathrm{ml}){ }^{39}$

\section{Coumarins in Dendrobium fimbriatum}

$\mathrm{Bi}$ et al. reported the isolation and purification of ayapin, which was further characterized by spectroscopical techniques from the orchid D. fimbriatum. ${ }^{40}$

\section{Coumarins in Habenaria intermedia}

Research carried out by Mahesh et al. has reported scopoletin in the tubers of H. intermedia. A further investigation against carbon tetrachloride-induced hepatitis in rats indicated hepatoprotective effect of scopoletin. $^{41}$

\section{Coumarins in Nervilia fordii}

A study by Tian et al. revealed the presence of esculetin in the whole plant of $N$. fordii. Further, antiherpes simplex virus 1 (HSV-1) activity of the isolated compounds was evaluated by cytopathic effect (CPE) assay. The results revealed a remarkable antiviral effect of esculetin compared to the other tested compounds showing a total inhibitory concentration (TIC) at $0.14 \mathrm{mM}$. Acyclovir was used as the standard control (TIC, $0.0043 \mathrm{mM}){ }^{42}$

\section{Coumarins in Spiranthes sinensis}

In a study by Peng et al., two new prenylatedcoumarins, namely sinensin A and sinensin B were reported in the roots of $S$. sinensis. Sinensin A and B are chemically 5- $\gamma, \gamma$-dimethylallyl-8-[2-(2,6dihydroxyphenyl)-3-dimethyl-but-2-enyol]-umbelliferon and 4,6- $\operatorname{di}(\gamma, \gamma$-dimethylallyl)-8-lavandulylumbelliferon respectively. ${ }^{43}$

\section{Orchids with coumarins remaining unrevealed}

The phytochemical screening of secondary metabolites in various parts of Eria tomentosa studied by Akter et al. revealed coumarins to be substantially higher in stems and roots compared to leaves. In contrast, the study by Sohag et al. showed higher coumarin content in the leaves and stems of Luisia zeylanica, than that in the roots. ${ }^{44,45}$ A preliminary phytochemical investigation of nine medicinal orchids of Bangladesh reported by Akter et al. indicated the presence of coumarins in Acampe praemorsa, Aerides odorata, Bulbophyllum lilacinum, Cymbidium aloifolium, Dendrobium aphyllum, Eria tomentosa, Geodorum densiflorum, Luisia zeylanica, Papilionanthe teres and Rhynchostylis retusa. ${ }^{46}$ However, isolation, identification and pharmacological screening of coumarins in these orchids remain uninvestigated. This existence of an incomplete bridge in the role of coumarins in Orchidaceae further directed the investigation upon ethnomedicine behind these orchids.

\section{Orchidaceae and Ethnomedicine}

Traditional folklore practices remain a primary source of traditional knowledge and a promising guide in natural products research. ${ }^{47}$ Even, most of the well-established natural leads have been developed from their traditional claims. ${ }^{48}$ The earliest documentation in orchids dates back to $28^{\text {th }}$ century B.C., when 
Emperor 'Shen-Nung' included Bletilla and Dendrobium species in 'Materia Medica'. ${ }^{9}$ Several ethnobotanical studies have documented the traditional uses of orchids against wounds, cuts, burns, boils, abscess, tumors, fever, bone fracture, menstrual disorders including heavy menstruation and abdominal pain, arthritis. ${ }^{30-32,35,36,46,50-58}$ A total of 19 orchids were reported with coumarins. The frequency of folklore claims of these orchids in treating several ailments under various ethno botanical surveys is depicted in Fig.-2.

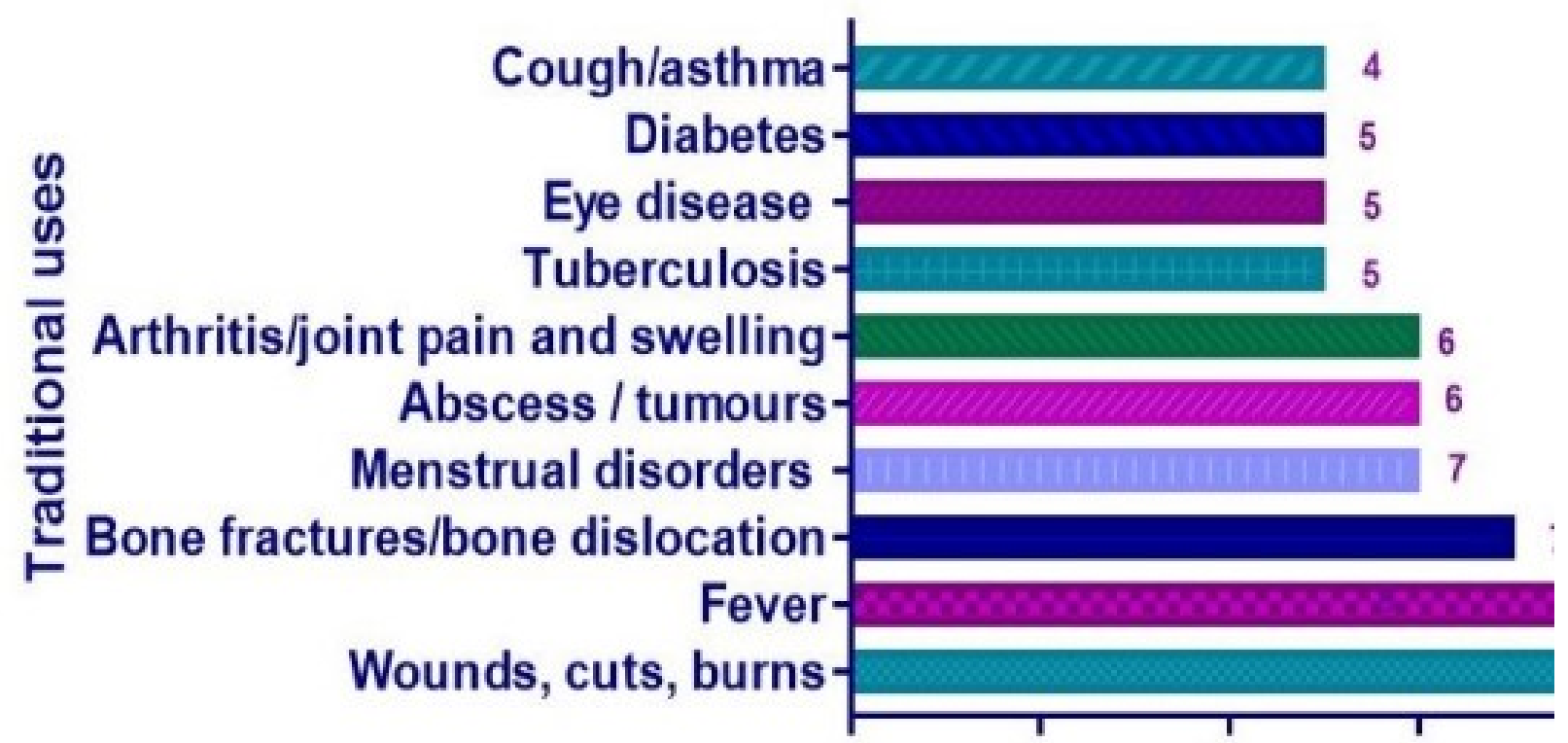

Fig.-2: Top 10 Traditional Uses of Orchids reported with Coumarins

CONCLUSION

Coumarins remain as an under-explored secondary metabolite in the family of Orchidaceae. The planar, aromatic and lipophilic nature of the $2 \mathrm{H}$-chromen-2-one ring allows better interaction with several protein targets exhibiting a wide range of pharmacological activity ${ }^{15}$ Apart from its scientifically proven potential against cancer, burns, cardiovascular and rheumatic diseases, reports on natural coumarins also add a special note on its unique anti-edema and anti-inflammatory activity that may be attributed to the presence of coumarin ring. ${ }^{59,60}$ Coumarins are reported to be found in abundance in the families of Apiaceae, Caprifoliaceae, Clusiaceae, Guttiferae, Nyctaginaceae, Oleaceae, and Rutaceae. ${ }^{61}$ Moreover, the long-established medicinal practice of orchids further kindles several therapeutic expectations, in turn, reflects an apparent lacuna in their transformation into scientific research. Hence, the current review will highlight the diversified biopharmacological activity of coumarin entity with a promising traditional background of Orchidaceae, leading to further phytochemical and phytopharmacological studies in orchid research.

\section{REFERENCES}

1. P. Pathak, R.N. Sehgal, N. Shekhar, M. Sharma, A. Sood, Orchids: Science and Commerce, 35 (2001).

2. M. Christenhusz, J. Byng, Phytotaxa, 261, 201(2016), https://doi.org/10.11646/phytotaxa.261.3.1

3. M. Hossain, Fitoterapia, 82, 102(2011), https://doi.org/10.1016/j.fitote.2010.09.007

4. J.M. Kong, N.K. Goh, L.S. Chia, T.F. Chia, Acta Pharmacologica Sinica, 24, 7(2003).

5. L.C. De, International Journal of Science, Environment and Technology, 9(4), 647(2020).

6. B. Pant, African Journal of Plant Science, 7(10), 448(2013), https://doi.org/10.5897/ajps2013.1031

7. D.M. Pereira, P. Valentao, J.A. Pereira, P.B. Andrade, Molecules, 14(6), 2202(2009), https://doi.org/10.3390/molecules14062202

8. F. Bourgaud, A. Hehn, R. Larbat, S. Doerper, E. Gontier, S. Kellner, U. Matern, Phytochemistry Reviews, 5, 293(2006), https://doi.org/10.1007/s11101-006-9040-2

9. S. Penta, Advances in Structure and Activity Relationship of Coumarin Derivatives, 1-8(2015), https://doi.org/10.1016/c2015-0-00450-6 
RASĀYAN J. Chem.

Vol. 14 | No. 4 |2591-2597| October- December | 2021

10. R. O'Kennedy, R.D. Thornes, Coumarins: Biology, Applications, and Mode of Action, 1 (1997).

11. R.S. Keri, B.S. Sasidhar, B.M. Nagaraja, M.A. Santos, European Journal of Medicinal Chemistry, 100, 257(2015), https://doi.org/10.1016/j.ejmech.2015.06.017

12. G.B. Bubols, D.R. Vianna, A. Medina-Remon, G. Von Poser, R.M. Lamuela-Raventos, V.L. EiflerLima, S.C. Garcia, Mini-Reviews in Medicinal Chemistry, 13, 318(2013), https://doi.org/10.2174/1389557511313030002

13. I. Najmanova, M. Dosedel, R. Hrdina, P. Anzenbacher, T. Filipsky, M. Ríha, P. Mladenka, Current $\begin{array}{lllll}\text { Topics in Medicinal Chemistry, } & \text { 15, }\end{array}$ https://doi.org/10.2174/1568026615666150220112437

14. I. Kostova, Current Medicinal Chemistry, 5, 29(2005), https://doi.org/10.2174/1568011053352550

15. A. Stefanachi, F. Leonetti, L. Pisani, M. Catto, A. Carotti, Molecules, 23(2), 250(2018), https://doi.org/10.1007/s11101-006-9040-2

16. F. Borges, F. Roleira, N. Milhazes, L. Santana, E. Uriarte, Current Medicinal Chemistry, 12, 887(2005), https://doi.org/10.2174/0929867053507315

17. S.E. Alessandra, G. Bertolt, L. Thomas, S. Li, K.F. Chater, L. Heide, Chemistry \& Biology, 10(3), $279(2003)$.

18. C.A. Kontogiorgis, D.J. Hadjipavlou-Litina, Journal of Medicinal Chemistry, 48, 6400(2005), https://doi.org/10.1021/jm0580149

19. T. Neichi, Y. Koshihara, S.I. Mutora, Biochimica et Biophysica Acta, 753, 130(1983), https://doi.org/10.1016/0005-2760(83)90106-6

20. Y. Kimura, H. Okuda, S. Arichi, K. Baba, M. Kozawa, Biochimica et Biophysica Acta, 834, 224(1985), https://doi.org/10.1016/0005-2760(85)90159-6

21. E.S. Teoh, Medicinal Orchids of Asia, 1 (2016), https://doi.org/10.1007/978-3-319-24274-3

22. N. Vaddhanaphuti, A Field Guide to the Wild Orchids of Thailand, 1 (2001).

23. T.C. Wrigley, Nature, 188, 1108(1960), https://doi.org/10.1038/1881108a0

24. G.N. Zhang, L.Y. Zhong, S.W. Bligh, Y.L. Guo, C.F. Zhang, M. Zang, Z. Wang, L. Xu, Phytochemistry, 66(10), 1113(2005), https://doi.org/10.1016/j.phytochem.2005.04.001

25. G. Zhang, F. Zhang, L. Yang, E. Zhu, Z. Wang, L. Xu, Z. Hu, Analytica Chimica Acta, 57(1), 17(2006), https://doi.org/10.1016/j.aca.2006.04.062

26. Y. Zheng, L. Xu, Z. Wang, C. Zhang, Acta Pharmaceutica Sinica, 40, 236(2005).

27. Y. Zheng, L. Xu, Z. Wang, C. Zhang, Zhongguo Zhong Yao Za Zhi, 34(9), 1071(2009).

28. Y. Zheng, L. Xu, Z. Wang, C. Zhang, African Journal of Biotechnology, 8(5), 794(2010).

29. Y. Liu, H. Yu, Y. Chen, Chemistry of Natural Compounds, 47(2), 275(2011), https://doi.org/10.1007/s10600-011-9902-8

30. A. Panda, D. Mandal, Ancient Science of Life, 33(2), 92(2013), https://doi.org/10.4103/02577941.139043

31. M. Hossain, Medicinal Aromatic Plant Science and Biotechnology, 3, 100(2009).

32. J. Tsering, N. Tam, D.R. Tag, B. Gogoi, O. Apang, Bulletin of Arunachal Forest Research, 32(1\&2), 1(2017).

33. W.P. Zheng, Y.P. Tang, F. Zhi, F.C. Lou, Journal of Asian Natural Products Research, 2(4), 301(2000), https://doi.org/10.1080/10286020008041369

34. C. Fan, W. Wang, Y. Wang, G. Qin, W. Zhao, W, Phytochemistry, 57(8), 1255(2001), https://doi.org/10.1016/s0031-9422(01)00168-6

35. M.M. San, K.W. Myint, Preliminary Survey on Medicinal Values of Some Dendrobium Species Occurring in Kutkai Township, Northern Shan State, 1 (2009).

36. R.R. Rao, Economic Botany, 35, 4(1981), https://doi.org/10.1007/bf02859208

37. D.C. Robustelli, C. Boselli, A. Papetti, J. Calevo, B. Mannucci, A. Tava, Natural Product Communications, 13, 93(2018), https://doi.org/10.1177/1934578x1801300127

38. H.M. Pan, B. Chen, F. Li, M.K. Wang, Chinese Journal of Applied and Environmental Biology, 19(6), 952(2013).

39. X. Zhou, B. Zhang, G. Chen, C. Han, K. Jiang, M. Luo, B. Meng, W. Li, S. Lin, Natural Product Research, 32(20), 1(2018), https://doi.org/10.1080/14786419.2017.1419241 


\section{RASĀYAN J. Chem.}

Vol. 14 | No. 4 |2591-2597| October- December | 2021

40. Z.M. Bi, Z.T. Wang, L.S. Xu, G.J. Xu, Yao Xue Xue Bao, 38(7), 526(2003).

41. A.G. Mahesh, H. Jayadevappa, K.M. Mahadevan, R.A. Shastry, P.V. Habbu, H.A. Sayeswara, International Journal of Current Pharmaceutical Research, 7(1), 57(2015).

42. L.W. Tian, Y. Pei, Y.J. Zhang, Y.F. Wang, C.R. Yang, Journal of Natural Products, 72(6), 1057(2009), https://doi.org/10.1021/np800760p

43. J.Y. Peng, X. Han, L.N. Xu, Y. Qi, Y.W. Xu, Q. Xu, Journal of Asian Natural Products Research, 10(3), 256(2008), https://doi.org/10.1080/10286020701605182

44. M.T. Akter, M.K. Huda, M.M. Hoque, M. Rahman, Orchid Biology: Recent Trends \& Challenges, pp.425-437(2020), https://doi.org/10.1007/978-981-32-9456-1

45. S.I. Sohag, M.M. Hoque, M.K. Huda, Journal of Pharmacognosy and Phytochemistry, 6(4), 688(2017).

46. M. Akter, M.K. Huda, M.M. Hoque, Journal of Pharmacognosy and Phytochemistry, 7(5), 602(2018).

47. A. Ghorbani, F. Naghibi, M. Mosaddegh, Iranian Journal of Pharmaceutical Sciences, 2, 109(2006).

48. C. Anyinam, Social Science \& Medicine, 5(4), 321(1995), https://doi.org/10.1016/02779536(94)E0098-D

49. M.A. Reinikka, A History of the Orchid, pp.246-249(1995)

50. A. Rajendran, N. Rao, K. Kumar, A. Henry, Ancient Science of Life, 17(1), 10(1997).

51. K.N. Reddy, G.V. Raju, C.S. Reddy, V.S. Raju, EPTRI-ENVIS News Letter, 11(3), 1(2005).

52. P.K. Dash, S. Sahoo, S. Bal, Ethnobotanical Leaflet, 12, 70(2008).

53. M. Akhter, M. Rahman, M. Hoque, M. Huda, Journal of Medicinal Plants Studies, 5(3), 265(2017).

54. S.R. Baral and P.P. Kurmi, A Compendium of Medicinal Plants in Nepal, 1 (2006).

55. B. Pant, B.B. Raskoti, Medicinal Orchids of Nepal, 1 (2013).

56. H. Karyamsetty, J.S.R. Aluri, EPTRI-ENVIS News Letter, 11(3), 2(2005).

57. World Health Organization, Medicinal plants in Vietnam, WHO Regional Office for the Western Pacific, Manila, 1 (1990).

58. Q. Huang, L. Liang, R. He, X. Ma, R. Zhan, W. Chen, Plant omics, 8(6), 493(2015).

59. C.A. Kontogiorgis, K. Savvoglou, D.J. Hadjipavlou-Litina, Journal of Enzyme Inhibition and Medicinal Chemistry, 21(1), 21(2006), https://doi.org/10.1080/14756360500323022

60. R.D.H. Murray, I. Mendez and S.A. Brawn, The Natural Coumarins, 1 (1982).

61. K.N. Venugopala, V. Rashmi, B. Odhav, BioMed Research International, 963248, 1(2013), https://doi.org/10.1155/2013/963248

[RJC-6529/2021] 